\title{
DELONIX REGIA BOJ. EX. HOOK RAFFIN; FAMILY: FABACEAE, BARK METHANOL EXTRACT PHYTOCHEMICAL PROFILE AND POTENTIAL THERAPEUTIC EVALUATION
}

\author{
ARPITHA SHIVAMALLU1 ${ }^{1}$, SHAILASREE SEKHAR ${ }^{2 *}$ \\ ${ }^{1}$ Scholar, Institution of Excellence, Vijnana Bhavana, University of Mysore, Mysuru. ${ }^{2}$ Scientist, Institution of Excellence, Vijnana Bhavana, \\ University of Mysore, Mysuru. Email: shailasree@ioe.uni-mysore.ac.in
}

Received: 21 February 2020, Revised and Accepted: 21 March 2020

\section{ABSTRACT}

Objectives: The aim of this study was to evaluate the antioxidant, anti-inflammatory, and anti-cancer potencies of the Delonix regia bark, a first of its kind.

Methods: The bark was extracted sequentially in Soxhlet apparatus with hexane, chloroform, and methanol in the increasing order of polarity. These extracts were subjected to find its antioxidant activity and total phenol content. Antibacterial activity against human pathogenic bacteria was tested. The anti-inflammatory properties were elucidated by its capacity to inhibit 15-lipoxygenase (LOX) and human cyclooxygenase (COX)-2. Cell cytotoxic capacity was evaluated against MCF-7 cells breast cancer cell lines.

Results: Liquid chromatography (LC)-Mass Spectroscopy (MS) fingerprint of the methanol extract identified a total of 14 polyphenols, of which five were structurally characterized based on their mass-charge ratio [M-H] ${ }^{-}$peak, UV-vis absorption in comparison to published data. Antibacterial activity by disk diffusion inhibited human pathogenic bacteria. Bacterial biofilm inhibition capacity of extract (750 $\mu \mathrm{g}$ ) imaged by confocal laser scanning microscopy revealed loss of microcolonies. Extract when tested for 15-LOX inhibition exhibited $\mathrm{IC}_{50}$ values of $94.5 \pm 1.23 \mu \mathrm{g} \cdot \mathrm{mL}^{-1}$ by enzyme kinetics studies using spectrophotometric techniques. Similarly, it could inhibit COX-2 enzyme at relatively lower concentrations $\left(32.18 \pm 1.91 \mu \mathrm{g} \cdot \mathrm{mL}^{-1}\right)$. Further, it quenched free radicals produced by Fentons' reagent studied by DNS-nicking assay indicating its strong antioxidant property with the capacity to protect DNA. In vitro cytotoxicity was evaluated by 3-(4,5-dimethylthylthiazol-2-yl)-2,5-diphynyl tetrazolium bromide assay and apoptosis induced in MCF-7 cells was assessed morphologically.

Conclusion: Our data suggest that D. regia bark methanol extract exerts its therapeutic activity for further pharmaceutical evaluations. Further studies are necessary to determine the mechanisms of these pharmacological properties.

Keywords: LC analysis in negative mode, Antioxidant, 15-LOX, COX-2, Biofilm by Confocal laser scanning microscopy, MCF-7 cells cytotoxicity.

(c) 2020 The Authors. Published by Innovare Academic Sciences Pvt Ltd. This is an open access article under the CC BY license (http://creativecommons. org/licenses/by/4. 0/) DOI: http://dx.doi.org/10.22159/ajpcr.2020.v13i10.38868

\section{INTRODUCTION}

Delonix regia, (Bojer. Ex. Hook) Raffin (Family: Fabaceae Caesalpinioideae) (synonyms - Poinciana regai, Bojer ex Hook.), is known to common man as Gul mohar, It is a medium sized ornamental tree grown in parks, gardens, and road side and has yellow-brown wood. It is also called a flamboyant or flame ornamental tree. The Indian Medicinal Plant Dictionary describes the white bark with traditional application as febrifuge and in healing wounds with anti-rheumatic and spasmogenic capacity. The aqueous and alcoholic flower extracts were used for roundworm removal [1]. Some of the properties reported for bark include relieving knee pain, emetic effect, as bio-monitors, and bio-accumulants of atmospheric trace metals. A 5\% chloroform was reported to have germicidal activity. The seeds were used in pyorrhea. The bark, fruits, and leaves have been used as anti-helminthic, reducing rheumatic pain and as purgatives in Pirojpur district, Bangladesh. The people of Yanadi (a tribal community in Andhra Pradesh, India) used flowers of Delonix regia in the treatment of dysmenorrhea $[2,3]$.

Human body metabolism generates free radicals as part of the normal metabolic process in the respiratory chain of mitochondrial mainly from drugs, xenobiotics, pollutants from atmosphere and metal (transitional) catalysts. An uncontrolled production of oxygen derived free radicals is associated with the onset of many diseases such as inflammation, cancer, rheumatoid arthritis, cirrhosis, arteriosclerosis, and degenerative processes associated with aging. Scavenging of reactive oxygen species (ROS) provides protection to DNA, proteins, and lipids reducing risk of chronic diseases. The synthetic antioxidants used include butylated hydroxyl toluene (BHT), butylated hydroxyl anisole, and ascorbic acid.

Value added products for enhancing the value of items of food by inclusion of an ingredient during processing and/or packaging is found to be attractive. It is received more favorable by the consumer. They could be products such as breakfast cereals or extruded snacks or ice creams. Microbial contaminations can make considerable changes in food items and finally affect the quality of these value added products. Microbial contaminations can adversely affect their shelf life. Benzoic acid, nitrites, and sulfites as antimicrobial agents are in wide use.

However, the uses of chemical preservatives are reported to be additive to major health hazardous and toxicity [4]. Thus, the use of natural preservatives has increased and finds acceptance by the consumers as a new approach to overcome on these adverse effects $[4,5]$.

Antioxidant and antimicrobial constituents in plant spices and herb tissues in bark, seed, roots, and flowers, among other parts provide these natural antioxidant and antimicrobial constituents.

Hence, the aim of this study was to evaluate the antioxidant, antiinflammatory, and anticancer potencies of the $D$. regia bark, a first of its kind. The polyphenols finger print of extract was carried out to identify confidently the polyphenols of the extracts. A differential concentration was then applied to study the antimicrobial property against Klebsiella pneumoniae, Escherichia coli, Pseudomonas aeruginosa, Staphylococcus aureus, and Bacillus subtilis and the results are presented 
in context to the observations. Other parameters screened were its possible anti-inflammatory activity, evaluated by its efficacy to inhibit 15-lipoxygenase (15-LOX) and human cyclooxygenase-2 (COX-2). The DNA protection property was evaluated by DNS-nicking assay using Fenton's reagent. Cell cytotoxicity studies by 3-(4,5-dimethylthylthiazol2-yl)-2,5-diphynyl tetrazolium bromide (MTT) assay and apoptosis induced were assessed morphologically by combined acridine orange and ethidium bromide staining for detecting incidence of cell cytotoxicity.

\section{METHODS}

\section{Plants}

The fresh bark $(50 \mathrm{~g})$ of test plant was collected during winter (January, 2019) from Kigga region of Western Ghats in Chikmagalur District of Karnataka State, and a herbarium specimen was deposited at Institution of Excellence (Delonix regia bark \# IOE LP0015). Fresh bark was washed, shade-dried, ground to a powder, and $100 \mathrm{~g}$ of powder were extracted 3 times by hexane, chloroform, and methanol $(1: 10 \mathrm{w} / \mathrm{v})$ at room temperature, evaporated to yield dry extracts in SpeedVac (Savant SPD 2010, Thermo Scientific), and stored under dark at $4^{\circ} \mathrm{C}$ until further use.

\section{Chemicals and reagents}

Trypsin, chloramphenicol, acridine orange, and ethidium bromide were purchased from Sigma-Aldrich (St. Louis, MO, USA). Linoleic acid, (+)-catechin, Luteolin, and 15-lipoxygenase (soybean) were purchased from Sigma-Aldrich (St. Louis, MO, USA). 1,1-diphenyl-2-picrylhydrazyl (DPPH), 2,2-azinobis-(3-ethylbenzthiazoline-6-sulfonic acid) (ABTS), 2-(4-Iodophenyl)-3-(4-nitrophenyl)-5-phenyltetrazolium chloride (INT), and MTT were purchased from Sigma-Aldrich (St. Louis, MO, USA). Standards quercetin, ascorbic acid (AA), and BHT were purchased from HiMedia (India). Nonessential amino acid, sodium bicarbonate, Eagle minimum essential medium, and L-glutamine were purchased from HiMedia (India). StepupTM 1kb DNA ladder and plasmid (pBR322) were from Merck Biosciences, Bengaluru (India). COX-2 inhibition kit was obtained from Cayman Chemicals, Ann Arbor, MI, USA. Minimum essential medium Eagle, sodium bicarbonate, L-glutamine, and nonessential amino acid were purchased from HiMedia (India). pBR322, plasmid and StepupTM (1kb) DNA ladder were obtained from Merck Biosciences, Bengaluru (India).

Estimation of total phenolic content and free-radical scavenging capacity of the extract

The total phenol content of the sample was estimated using the FolinCiocalteu colorimetric method [6]. The methanol extracts $(50,100$, 250 , and $500 \mu \mathrm{g} \cdot \mathrm{mL}^{-1}, 1,5$, and $10 \mathrm{mg} \cdot \mathrm{mL}^{-1}$ ) were evaluated for their antioxidant activity. Two methods used were DPPH scavenging assay and 2,2-azinobis-(3-ethylbenzthiazoline-6-sulfonic acid (ABTS ${ }^{+}$) assay $[7,8]$. The results were compared with the most commonly used synthetic antioxidants BHT, quercetin, and AA. The antioxidant activity was expressed as $\mathrm{IC}_{50}$ values.

\section{Bacterial strains and culture conditions}

The Institute of Microbial Technology, Chandigarh, India, kindly provided the Gram (-) bacteria, Klebsiella pneumoniae (MTCC 661), Escherichia coli (MTCC 724), Pseudomonas aeruginosa (ATCC 27853), and Gram (+) bacteria, namely, Staphylococcus aureus (ATCC 25923) and Bacillus subtilis (MTCC 441). Bacterial inoculums were prepared by growing cells in Mueller-Hinton Broth (MHA) (HiMedia, India) for $24 \mathrm{~h}$ at $37^{\circ} \mathrm{C}$. These cell suspensions were diluted with sterile MHB to provide initial cell counts of about $10^{4} \mathrm{CFU} \cdot \mathrm{mL}^{-1}$.

\section{Antibacterial activity}

\section{Agar-disk diffusion method}

Disk diffusion was carried out with the above said samples. An aliquot ( 5 and $10 \mu \mathrm{L} ; 1 \mathrm{mg} . \mathrm{mL}^{-1}$ ) was introduced on the disks ( $0.7 \mathrm{~cm}$; HiMedia) for this experiment. The diameter of inhibition zones was recorded and was compared against streptomycin (positive standard; $3 \mu \mathrm{L}$ of $1 \mathrm{mg} . \mathrm{mL}^{-1}$; Sigma-Aldrich St. Louis, MO, USA) and methanol (negative standard; $10 \mu \mathrm{L}$ ) under similar experimental conditions.
Minimum inhibitory concentration (MIC)

Micro-dilution methods of broth were used for measuring MIC. Muller-Hinton Broth (MHB; Merck Biosciences, Bangalore, India) was used [9]. A two-fold serially diluted extract $(50 \mu \mathrm{L})$ of $D$. regia extract in methanol with concentration range of $10,5,1.25,0.625$, $0.3125,0.15625,0.078125$, and $0.0390605 \mathrm{mg} \cdot \mathrm{mL}^{-1}$ was added to the 96-well micro-titer plate. The bacterial suspension $(50 \mu \mathrm{L})$ in MHB $\left(10^{4} \mathrm{CFU} . \mathrm{mL}^{-1}\right)$ was introduced. Control wells include wells with culture medium (sterility control) and the extracts. Wells with methanol were the positive control. MHB ( $50 \mu \mathrm{L})$ wells were negative control. Bacterial suspension in MHB $(50 \mu \mathrm{L})$ was positive control. The contents of each well were mixed. The MIC was defined as the lowest concentration where no viability was observed after $24 \mathrm{~h}$. This was assessed on the basis of metabolic activity visualized as purple color. It is the results produced by addition of 2-(4-Iodophenyl)-3-(4-nitrophenyl)-5phenyltetrazolium chloride (INT), and dissolved in water $(10 \mu \mathrm{L}$ of INT, $\left.2 \mathrm{mg} \cdot \mathrm{mL}^{-1}\right)$. The plates were incubated in the dark $\left(37^{\circ} \mathrm{C}\right.$ for $\left.30 \mathrm{~min}\right)$ after addition of INT. All measurements of MIC values were repeated in triplicate. Chloramphenicol was used as positive control.

Confocal laser scanning microscopy (CLSM) study to assay loss of biofilm To observe the biofilm structure, CLSM, LSM 710 (Carl Zeiss, Germany) was used. The samples were prepared according to Zhang et al. [10]. The overnight cultures of Pseudomonas aeruginosa and Staphylococcus aureus were prepared with the absorbance set at $1.5 \pm 2.0(600 \mathrm{~nm})$. The assay was conducted in a 6-well plate. Cover slips were placed in all the wells and above the cover slip about $2 \mathrm{ml}$ of the media was added. The cover slip with media was maintained as control. To the test wells, overnight bacterial suspensions $(750 \mu \mathrm{l})$ were introduced. The extracts $(200 \mu \mathrm{L}, 750 \mu \mathrm{g})$ were added. The plates were incubated at $37^{\circ} \mathrm{C}$ for $24 \mathrm{~h}$. The biofilm formed on cover slips in wells were removed carefully. The biofilm was washed with PBS. The film was stained with ethidium bromide ( $20 \mu \mathrm{L} ; 1 \mathrm{mg}$ in $400 \mu \mathrm{L}$; HiMedia, India). After three washes, the cover slips with stained biofilm were placed on glass slide in an inverted position. CLSM images of the samples were imaged and results were presented.

\section{Anti-inflammatory activity \\ Lipoxygenase (15-LOX) Inhibition}

A spectrophotometric assay for the determination of soybean 15-LOX ( $5 \mu \mathrm{g}$; Sigma- Aldrich, St. Louis, MO, USA) activity with $0.2 \mu \mathrm{M}$ linoleic acid (substrate; Sigma-Aldrich, St. Louis, MO, USA) in buffer $(0.2 \mathrm{M}$ borate buffer ( $\mathrm{pH} 9.0)$ was carried out. The extracts at 10,25 , 50,75 , and $100 \mu \mathrm{g} \cdot \mathrm{mL}^{-1}$ were used for inhibition studies. The values of hydroperoxide content were estimated. The LOX activity was calculated as reported earlier [11]. The results were compared with AA, BHT, and quercetin, the most potent LOX inhibitors.

\section{COX-2 inhibition}

COX-2 inhibition kit was obtained from Cayman Chemicals, Ann Arbor, MI, USA. COX-2 inhibition by the extract was measured using a COX-2 inhibitor (human) screening kit (Cayman, Ann Arbor, MI, USA) by colorimetric estimation. The samples $(100 \mu \mathrm{g})$ of the extract were used for inhibition studies as per manufacturer's protocol. The absorbance was read at $415 \mathrm{~nm}$ in a micro-titer plate reader (Varioskan Flash with SkanIt) with Software RE 2.4.3. The results were compared with AA, BHT, and quercetin, the most potent LOX inhibitors.

\section{DNA strand scission assay}

A DNA-strand scission assay was performed using super-coiled plasmid pBR322 (Merck Biosciences, Bengaluru, India) [12]. Mixture of $5 \mu \mathrm{l}$ of extract $(1 \mathrm{mg} / \mathrm{ml})$ and $2 \mu \mathrm{l}$ of plasmid were added to $5 \mu \mathrm{l}$ of Fenton's reagent $\left(30 \mathrm{mM} \mathrm{H}_{2} \mathrm{O}_{2}, 50 \mu \mathrm{M}\right.$ ascorbic acid and $\left.80 \mu \mathrm{M} \mathrm{FeCl}_{3}\right)$. The final volume was made up to $15 \mu \mathrm{l}$ with sterile water followed by incubating for $30 \mathrm{~min}$ at $37^{\circ} \mathrm{C}$. The DNA was analyzed on $1 \%$ agarose gel using ethidium bromide staining. The results were documented using XR+ Molecular Imager Gel documentation system (BioRad, USA). 
Liquid chromatography (LC) analysis of methanol extract in negative mode

Synapt G2 (UPLC separations with QuanTof) was used for the qualitative analysis of the metabolites [13] according to manufacturer's protocol. The nebulizer pressure was $60 \mathrm{psi}$ at a drying temperature of $350^{\circ} \mathrm{C}$ and the nitrogen flow rate $10 \mathrm{~L} / \mathrm{min}$ was used. The methanol bark extract was filtered ( 0.2 micron syringe filters, Millipore, U.S.A) and an aliquot $(5 \mu \mathrm{l})$ was injected into the system. The $\mathrm{m} / \mathrm{z} 100-1000$ in negative ionization mode mass spectra were acquired. The collision gas helium was used for the fragmentation in the ion trap of the isolated compounds. The detection conditions were as follows: Capillary voltage, $3500 \mathrm{~V}$; skimmer voltage, $-40 \mathrm{~V}$; cap exit voltage, $-158.5 \mathrm{~V}$; Oct $1 \mathrm{DC},-12 \mathrm{~V}$; Oct $2 \mathrm{DC},-2.45 \mathrm{~V}$; trap drive level, 45.0; Oct RF, $150 \mathrm{Vpp}$; Lens 1, 5.0 V; and Lens 2, $60 \mathrm{~V}$.

\section{Cell cytotoxicity assay}

\section{MTT assay}

MCF-7 (breast cancer cell lines) were maintained in minimum essential medium (Eagle) with $2 \mathrm{mM} \mathrm{L-glutamine} \mathrm{and} \mathrm{Earle's} \mathrm{salts.} \mathrm{The} \mathrm{cytotoxic}$ evaluation was performed by MTT method. Trypsinized cells were washed with culture medium. Briefly, the cell cultures $\left(5 \times 10^{5}\right.$ cells. $\left.\mathrm{mL}^{-1}\right)$ were prepared in a 96-well flat-bottomed plate and incubated for $48 \mathrm{~h}$ at $37^{\circ} \mathrm{C}$ in humidified $5 \% \mathrm{CO}_{2}$. Methanol extract $(2,4,6,8,10$, or $15 \mathrm{mg} / \mathrm{mL}$ filtered through $0.22-\mu \mathrm{m}$ filters $)$ and camptothecin $(0.1,1,5$, and $10 \mu \mathrm{g} / \mathrm{mL})$ were added to the appropriate wells and incubated (48 h). MTT dissolved in PBS $(5 \mathrm{mg} / \mathrm{mL} ; 10 \mu \mathrm{L})$ was added to each well. They were incubated in dark $(4 \mathrm{~h})$. The supernatants were aspirated from the wells. Further washes were with Dulbecco's formula phosphate-buffered saline (PBS, $\mathrm{pH}$ 7.3). For solubilization of the resultant formazan product, DMSO $(100 \mu \mathrm{L})$ and $25 \mu \mathrm{L}$ of $0.1 \mathrm{M}$ glycine buffer (pH 10.5) were added, followed by incubation $\left(4 \mathrm{~h}\right.$ at $\left.37^{\circ} \mathrm{C}\right)$ and the absorbance $(570 \mathrm{~nm})$ was measured at (VarioskanTM Flash Multimode Reader, Thermo Scientific). Controls consisted of cells at same concentration. The $\mathrm{IC}_{50}$ for sample was obtained from dose-effect curves (not shown) an average of three assays with six concentrations was reported.

Cytotoxicity of $D$. regia extract on MCF-7 cells visualization by acridine orange (AO) - ethidium bromide (EtBr) staining

The analysis of morphological changes to assess the cell death in the in vivo treated MCF-7 cells was performed using $\mathrm{AO}$ and EtBr combostain. Harvested MCF-7 cells ( $48 \mathrm{~h}$ ) from control, D. regia bark methanol extract $\left(6 \mathrm{mg} \cdot \mathrm{mL}^{-1}\right)$ and camptothecin $\left(1 \mu \mathrm{g} \cdot \mathrm{mL}^{-1}\right)$ were washed with PBS washed 3 times in PBS (clears excess of staining components). Control consisted of cells with no treatment. The AO and EtBr stain (25 $\mu \mathrm{L} ; 1 \mathrm{mg} \cdot \mathrm{mL}^{-1}$ with $0.1 \%$ acetic acid and methanol) was added to the cell pellet in PBS $(100 \mu \mathrm{L})$. The cells were placed on a microscopic slide. It was covered with a cover slip and sealed. The fluorescence was recorded using CLSM, LSM 710 (Carl Zeiss, Germany).

\section{Statistical analysis}

All experiments and measurements were made in triplicate. The values are expressed as the mean \pm S.E.M. The results were subjected to variance analysis followed by Tukeys' test to analyze differences between the $D$. regia extract and control conditions. Statistically significant differences $(\mathrm{p}<0.001)$ were shown.

\section{RESULTS}

\section{LC analysis of methanol extract in negative mode}

Polyphenol extraction was achieved using methanol as a solvent by applying sequential-liquid extraction. The LC-chromatogram obtained is shown in Fig. 1, and peaks were labeled according to the order of their retention time. Structural characterization was performed using the retention time of standards and published data [13]. (+)-catechin and $(+)$-Luteolin were used as standards in this experiment. The presence of unknown phytoconstituents, 1-caffeoylquinic acid, 3-Caffeoylquinic acid, Luteolin dihexoside, 6,8-C-C-diglucosyl apigenin, and diosmetin 7-0-diglucoside was identified. Table 1 and Fig. 1 summarize the LC-MS data and phytoconstituents of $D$. regia extract details.
DPPH and ABTS radical scavenging assay

The percentage of DPPH decolorization is attributed to hydrogen donating ability of test compounds. Variable DPPH and ABTS activities were recorded when compared to the reference standards ascorbic acid, BHT, and quercetin (Table 2). Total phenol content is also reported $(252 \pm 3.231 \mu \mathrm{g} / \mathrm{g}$ dry weight).

\section{Antibacterial activity}

Agar-disk diffusion method

Zone of inhibition studies by agar-disk diffusion method exhibited a clear antimicrobial effect of the extract. A statistically significant inhibition of both gram (-) and gram $(+)$ bacteria was recorded (Fig. 2).

MIC

These extracts were assessed for their efficiency on the bacteria by MIC analysis by broth microdilution method. It was observed that the extract was very effective against all the bacterial strains tested (Table 3). It could inhibit most of the E. coli growth with the best MIC of $103.7 \mu \mathrm{g} \cdot \mathrm{mL}^{-1}$.

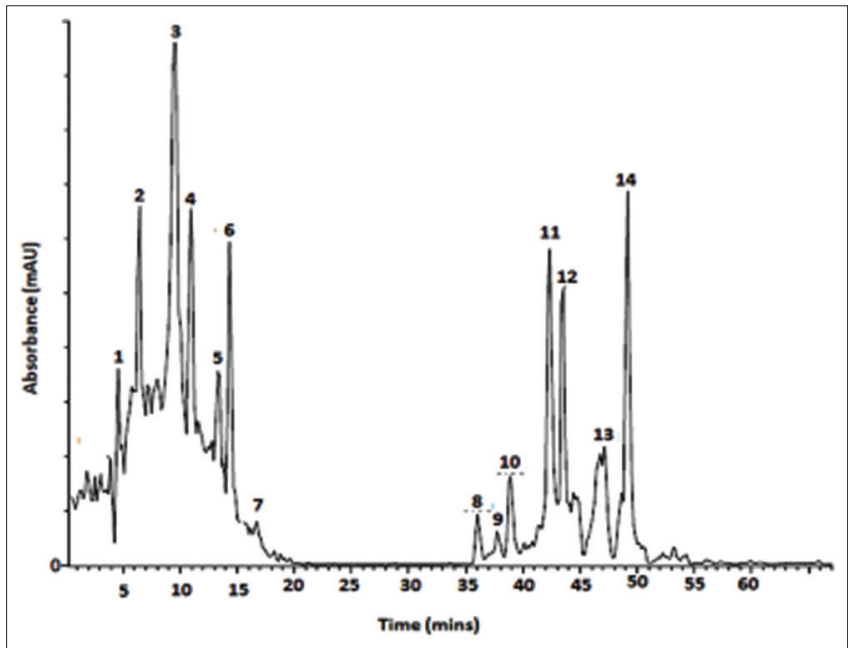

Fig. 1: LC analysis of Delonix regia barks methanol extract in negative mode.

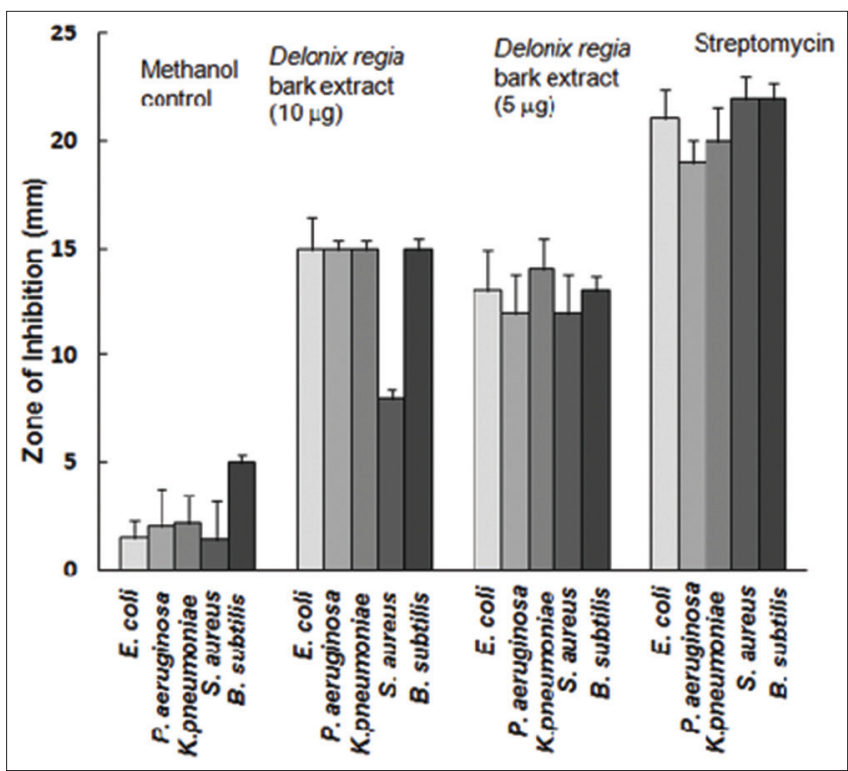

Fig. 2: Antibacterial activity assayed by disk diffusion method and its quantitative results. *Values are expressed as the mean \pm SEM (Standard Error Mean) ( $n=3)$ : *Indicates $\mathbf{p}<0.001$ 
CLSM observation of biofilm

Gram (+) strain, Staphylococcus aureus (ATCC 25923) and gram (-) strain, Pseudomonas aeruginosa (ATCC 27853) commonly reported as biofilm forming strains were included in this study. From sample observations of controls, S. aureus (Fig. 3a) and P. aeruginosa (Fig. 3c) formed an biofilm on the support. The addition of the extract $(200 \mu \mathrm{L}, 750 \mu \mathrm{g})$ resulted in a loss in the biofilm. A significant biofilm inhibition was visualized by CLSM studies. Patches and broken down of the biofilm architecture and with decreased microcolonies containing S. aureus (Fig. 3 b) and P. aeruginosa (Fig. $3 \mathrm{~d}$ ) was recorded.

\section{Anti-inflammatory activity}

\section{Lipoxygenase (15-LOX) Inhibition}

The samples could inhibit 15-LOX to various capacities (Table 4). Of the reference standards, quercetin exhibited potent capacity inhibiting with $\mathrm{IC}_{50} 3.7 \pm 0.22 \mu \mathrm{g} \cdot \mathrm{ml}^{-1}$ followed by ascorbic acid and BHT. The D. regia extract exhibited $\mathrm{IC}_{50}$ of $114.5 \pm 0.53 \mu \mathrm{g} \cdot \mathrm{ml}^{-1}$ nearer to reference standard BHT indicating potent 15-LOX inhibition (Table 4).

\section{COX-2 Inhibition}

Inhibitory COX-2 effect $\left(\mathrm{IC}_{50}\right)$ of $D$. regia bark extract was at $62.18 \pm 3.14 \mu \mathrm{g} \cdot \mathrm{mL}^{-1}$ by in vitro enzymatic activities measured against

Table 1: LC fingerprint and phytochemicals identified from Delonix regia bark methanol extract $(\mathrm{n}=3)$

\begin{tabular}{llll}
\hline $\begin{array}{l}\text { Peak } \\
\text { no. }\end{array}$ & Compound & $\begin{array}{l}\text { Retention } \\
\text { time (min) }\end{array}$ & References \\
\hline 1 & unknown & 5.19 & {$[13]$} \\
2 & Unknown & 7.94 & {$[20]$} \\
3 & 1-caffeoylquinic acid & 10.34 & {$[13]$} \\
4 & 3-Caffeoylquinic acid & 10.84 & {$[21]$} \\
5 & Luteolin dihexoside & 13.76 & {$[21]$} \\
6 & (+)-catechin (STD) & 14.93 & {$[13]$} \\
7 & 6,8-C-C-diglucosyl apigenin & 15.79 & {$[21]$} \\
8 & Diosmetin 7-O-diglucoside & 35.26 & {$[21]$} \\
9 & Luteolin (STD) & 36.92 & {$[13]$} \\
10 & unknown & 39.59 & {$[13]$} \\
11 & unknown & 42.26 & {$[13]$} \\
12 & unknown & 43.12 & {$[13]$} \\
13 & unknown & 46.14 & {$[13]$} \\
14 & unknown & 49.79 & {$[13]$} \\
\hline$*$ The identification of phytoconstituents was verified from three independent
\end{tabular}

LC-MS spectra of the extract and is presented in the table. human COX-2. However, the standards exhibited a lower $\mathrm{IC}_{50}$ values indicating their capacity to inhibit COX-2 (Table 5).

\section{DNA strand scission assay for DNA protection studies}

Protecting DNA from damage was investigated. The efficacy of the extracts was tested. The plasmid DNA (pBR322) was exposed to Fenton reagent used as source of hydroxyl radical $\left(30 \mathrm{~min}\right.$ at $\left.37^{\circ} \mathrm{C}\right)$. Fenton reagent induced a super-shift in native double-stranded DNA band (Form I) to single-stranded, nicked DNA (Form II) as indicated by arrows was confirmed in agarose gel electrophoresis. The plasmid DNA was damaged by Fenton reagent resulting in super shift in native double-stranded DNA band (Form I) to single-stranded (as indicated by arrows), nicked DNA (Form II) as visualized in agarose gel electrophoresis (Fig. 4). In comparison, when plasmid DNA was preincubated with $10 \mu \mathrm{g}$ of extract for $30 \mathrm{~min}$ and later exposed to Fenton reaction under similar conditions as above, D. regia extract could prevent scission. It offered prominent protection to DNA.

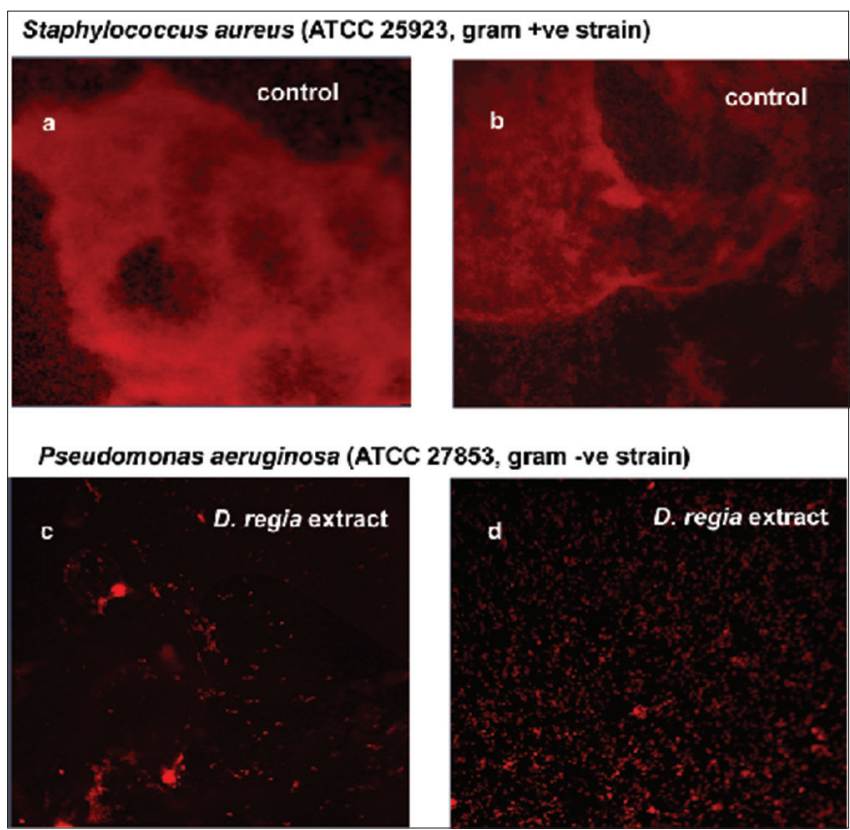

Fig. 3: Biofilm inhibition assay of Delonix regia bark methanol extract. Controls, Staphylococcus aureus (a); Pseudomonas aeruginosa (c). D. regia $+S$. aureus (b); D. regia $+P$ aeruginosa (d). The data are representative of three independent experiments $(n=3)$.

Table 2: DPPH and ABTS antioxidant activities* $(n=3)$. Total phenol content of Delonix regia bark methanol extracts $(n=3)$

\begin{tabular}{lll}
\hline Samples & $\begin{array}{l}\text { DPPH assay } \\
\text { (IC }_{\mathbf{5 0}} \text { value in } \boldsymbol{\mu g} \cdot \mathbf{m l}^{\mathbf{1}} \text { ) }\end{array}$ & $\begin{array}{l}\text { ABTS assay } \\
\text { (IC }_{\mathbf{5 0}} \text { value }\left(\boldsymbol{\mu g} \cdot \mathbf{m l}^{-\mathbf{1}}\right)\end{array}$ \\
\hline D. regia bark methanol extract & $81 \pm 2.12$ & $69 \pm 1.23$ \\
Ascorbic acid & $66 \pm 3.12$ & $59 \pm 2.09$ \\
BHT & $58 \pm 1.02$ & $47 \pm 1.06$ \\
Quercetin & $28 \pm 1.32$ & $19 \pm 2.03$ \\
\hline
\end{tabular}

*Values are expressed as the mean \pm SEM $(\mathrm{n}=3):{ }^{*}$ indicates $\mathrm{p}<0.001$

Table 3: Minimal inhibitory concentration* $\left(\mu \mathrm{g} \cdot \mathrm{mL}^{-1}\right)$

\begin{tabular}{|c|c|c|c|c|c|}
\hline Samples & $\begin{array}{l}\text { Escherichia coli } \\
\text { (-ve) }\end{array}$ & $\begin{array}{l}\text { Pseudomonas aeruginosa } \\
\text { (-ve) }\end{array}$ & $\begin{array}{l}\text { Klebsiella pneumoniae } \\
\text { (-ve) }\end{array}$ & $\begin{array}{l}\text { Staphylococcus aureus } \\
\text { (+ve) }\end{array}$ & $\begin{array}{l}\text { Bacillus } \\
\text { subtilis (+ve) }\end{array}$ \\
\hline $\begin{array}{l}\text { D. regia bark methanol } \\
\text { extract ( } 5 \mathrm{mg} \text { ) }\end{array}$ & $143.2^{\mathrm{b}}$ & $147.72^{\mathrm{c}}$ & $148.36^{c}$ & $153.82^{\mathrm{cd}}$ & $142.32^{\mathrm{b}}$ \\
\hline $\begin{array}{l}\text { D. regia bark methanol } \\
\text { extract }(10 \mathrm{mg})\end{array}$ & $103.7^{\mathrm{a}}$ & $114.06^{\mathrm{a}}$ & $133.14^{\mathrm{a}}$ & $131.14^{\mathrm{a}}$ & $116.28^{\mathrm{a}}$ \\
\hline Chloramphenicol & 25.42 & 36.21 & 16.23 & 64.18 & 36.14 \\
\hline
\end{tabular}

*Values are expressed as the mean \pm SEM $(n=3)$ : *Indicates $\mathrm{p}<0.001$, one-way ANOVA, followed by Tukeys' test 
M, DNA ladder (1 kb); Lane 1, pBR322 (native plasmid DNA); Lane 2, pBR322 DNA +Fenton reagent; Lane 3, pBR322 + D. regia bark methanol extract + Fenton reagent.

\section{Cytotoxicity assay}

$I C_{50}$ is a useful parameter for quantification of drug effect on cell survival. The effect of increasing concentration of extracts on the cytotoxicity to MCF-7 cells was measured by MTT assay. A dose-dependent curve identified the $\mathrm{IC}_{50}$ value of $6.31 \pm 2.71 \mathrm{mg} \cdot \mathrm{mL}^{-1}$ for the extract (Table 6). The positive control, camptothecin assayed for cytotoxicity under similar conditions exhibited $\mathrm{IC}_{50}$ of $1.28 \pm 3.11 \mathrm{mg} \cdot \mathrm{mL}^{-1}$.

Cytotoxicity of $D$. regia extract on MCF-7 cells visualization by acridine orange (AO) - ethidium bromide (EtBr) staining for morphological observation of cell structure by CLSM

MCF-7 cells, control groups, and post-treatment with D. regia extract were stained with combo of acridine orange $(\mathrm{AO})$ and ethidium bromide (Etbr). The cell morphology was captured by a CLSM microscope. Control cells did not exhibit significant morphological changes and were green. However, the cells from the D. regia and camptothecin groups showed the signs loss of cell morphology and an uptake of Etbr indicating a loss of cell membrane morphology. The camptothecin (1 mg.mL ${ }^{-1}$ ) treatment resulted in formation of fragmented nuclei with condensed chromatin (Fig. 5). D. regia $\left(6 \mathrm{mg} \cdot \mathrm{mL}^{-1}\right)$ treatment significantly decreased cell viability by $64.7 \%$ inducing apoptosis.

\section{DISCUSSION}

Quality control of plant extracts involving its standardization is an important topic, in particular, when such extracts are used for medicinal purposes [14]. The negative ion mode ESI-MS is particularly effective for characterization of plant extracts $[13,15]$. Polyphenols, the secondary metabolites with health benefits have been center of several studies as they cannot be synthesized by human [15]. Fingerprint profiling $D$. regia bark methanol extract for polyphenols in the present study identified the presence of several molecules and six could be identified and reported [16]. 1-caffeoylquinic acid and 3-Caffeoylquinic acid prevent

Table 4: Inhibition of 15-lipoxygenase* $(n=3)$

\begin{tabular}{ll}
\hline Samples & $\begin{array}{l}\text { 15-Lipoxygenase inhibition } \\
\left(\mathbf{I C}_{\mathbf{5 0}}, \boldsymbol{\mu g} \cdot \mathbf{m L}^{-\mathbf{1}}\right)\end{array}$ \\
\hline D. regia bark methanol extract & $114.5 \pm 0.53$ \\
Ascorbic acid & $7.58 \pm 2.41$ \\
BHT & $90.37 \pm 1.32$ \\
Quercetin & $3.7 \pm 0.22$ \\
\hline
\end{tabular}

*Values are expressed as the mean \pm SEM $(\mathrm{n}=3)$ : ${ }^{*}$ Indicates $\mathrm{p}<0.001$, one-way ANOVA, followed by Tukeys' test.

Table 5: Inhibition of cyclooxygenase-2* assayed by human COX-2 inhibitor screening kit (Cayman, Ann Arbor, MI, USA) by colorimetric estimation $(n=2)$

\begin{tabular}{ll}
\hline Samples & COX-2 inhibition $\left(\mathrm{IC}_{\mathbf{5 0}}, \boldsymbol{\mu g} \cdot \mathbf{m L}^{-\mathbf{1}}\right)$ \\
\hline D. regia bark methanol extract & $62.18 \pm 3.14$ \\
Ascorbic acid & $21.1 \pm 2.11$ \\
BHT & $5.65 \pm 2.02$ \\
Quercetin & $15.65 \pm 3.11$
\end{tabular}

*Values are expressed as the mean \pm SEM $(n=3)$ : ${ }^{*}$ Indicates $p<0.001$, one-way ANOVA, followed by Tukeys' test.

Table 6: Cell cytotoxicity studies on MCF-7 cells

\begin{tabular}{ll}
\hline Samples & IC $_{\mathbf{5 0}}$ \\
\hline D. regia bark methanol extract & $6.31 \pm 2.71 \mathrm{mg} \cdot \mathrm{mL}^{-1}$ \\
Camptothecin & $1.28 \pm 3.11 \mu \mathrm{g} \cdot \mathrm{mL}^{-1}$ \\
\hline
\end{tabular}

*Values are expressed as the mean \pm SEM $(n=3):{ }^{*}$ Indicates $\mathrm{p}<0.001$, one-way ANOVA, followed by Tukeys' test cell proliferation of carcinoma cells such as adenocarcinoma gastric (AGS) cell line [17], Luteolin dihexoside, a flavonoid, and suppresses cell survival pathways such as phosphatidylinositol 3'-kinase (PI3K)/ Akt, nuclear factor kappa B (NF- $\mathrm{KB})$, and X-linked inhibitor of apoptosis protein (XIAP). It stimulates apoptotic pathways including those that induce the tumor suppressor p53 [18], Diosmetin 7-0-diglucoside protects against carcinogenesis [19] are strongest natural antioxidant agents as indicated with references above. The presence of these polyphenols in the study material could also support the therapeutic property of D. regia bark for mentioned applications in Khare [3]. The previous studies have demonstrated antioxidant capacity of $D$. regia leaves extracts [1,2]. However, to date, no studies have extensively investigated the bioactivity of extracts of $D$. regia bark in terms of broad range pharmacological therapeutic capacity and elucidation of its mechanism.

In the present study, Soxhlet methanolic extract of bark from D. regia was examined for its activity. It quenched free radicals produced by Fentons' reagent studied by DNA-nicking assay indicating its strong antioxidant property with the capacity to protect DNA. In vitro cytotoxicity was evaluated by MTT assay and apoptosis induction was assessed morphologically. Thus, it had the capacity to suppress ROS and exhibited cytotoxicity to the tested cancer cell lines. Extract when tested for 15 -LOX inhibition exhibited $\mathrm{IC}_{50}$ values of $94.5 \pm 1.23$ by enzyme kinetics studies using spectrophotometric techniques. Similarly, it could inhibit COX-2 enzyme at relatively lower concentrations.

Antibacterial activity by disk diffusion inhibited human pathogenic bacteria. Bacterial biofilm inhibition capacity of extract $(750 \mu \mathrm{g})$ imaged by CLSM revealed loss of microcolonies.

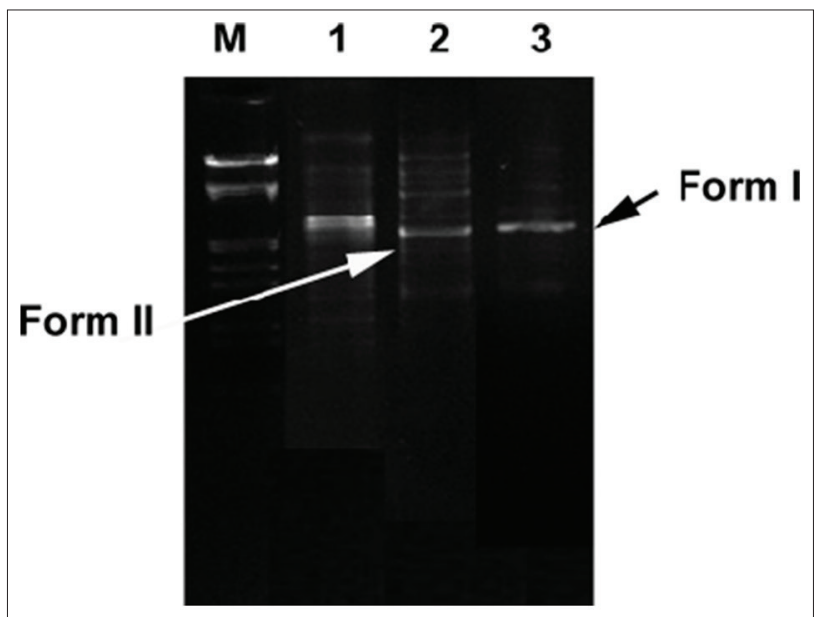

Fig. 4: DNA Strand Scission Assay for DNA protection studies. The data are representative of three independent experiments $(n=3)$.

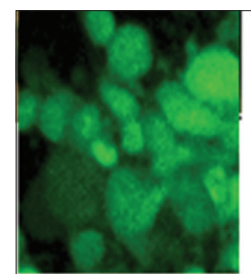

Control

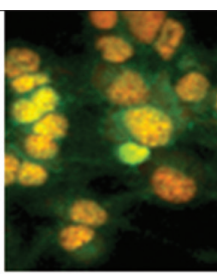

D. regia bark methano extract $(6 \mathrm{mg} \cdot \mathrm{mL}-1)$

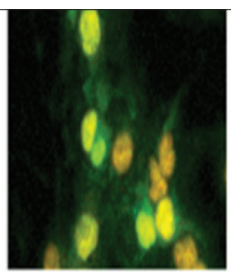

Camptothecin $(1 \mu \mathrm{g} \cdot \mathrm{mL}-1)$
Fig. 5: Cell cytotoxicity analysis of MCF-7 cells. MCF-cells (control cells), MCF-7 cells + D. regia bark methanol extract (6mg.mL $\mathrm{mL}^{-1}$ ) and MCF-7 cells + camptothecin (1 microg. $\mathrm{mL}^{-1}$ ). Apoptotic characteristics of chromatin condensation were observed. The data are representative of three independent experiments $(n=3)$. 
Bacterial infections lead to pneumonia and tuberculosis, common respiratory tract infection in humans leading to an inflammatory condition of parenchyma tissue of lung. It is caused due to several bacterial pathogens such as Streptococcus pneumoniae, Pseudomonas aeruginosa, and Staphylococcus aureus. Pneumonia is currently identified as most widespread infection [22,23]. Finding alternative affordable treatments to local populations has been an important field in ethnopharmacological investigations [24]. Although the traditional use of the extract for antimicrobial activity is known, the need for identification of exact active phytoconstitutents is a requirement for standardizing traditional medicine [25]. Further work for toxicology assessment of the extract and formulations [26] is underway.

The selected plant had many proven therapeutic properties and, possibly, successively united onto the sort of potential therapeutic plants. Besides, isolation and discoveries will lead to the detection of certain novel compounds, which will be of potential medicinal value.

\section{CONCLUSION}

Taken together, our data suggest that $D$. regia bark methanol extract might exert its antioxidant activity, anti-inflammatory, and anticancer activity. Any study of the properties of medicinal plants should consider the qualitative and quantitative composition of phytochemicals present in the raw material. Its metabolism, bioavailability, absorption, and distribution on intake could be the next step for development of drugs from vast plant resources.

\section{CONFLICTS OF INTEREST}

The authors have no conflicts of interest.

\section{AUTHOR'S FUNDING}

AS and SS acknowledge the financial support given by the University Grants Commission, New Delhi, India, and Institution of Excellence at the University of Mysore granted by the Ministry of Human Resource Development, Government of India, New Delhi, India, UOM/IOE/ RESEARCH/I/2010-11, dt 22.04.2010 for the facilities.

\section{AUTHOR'S CONTRIBUTIONS}

AS performed the extraction and antioxidant study and analyzed the data. SS performed the anti-biofilm and MCF-7 cell cytotoxicity assays. Both drafted the manuscript and edited the same. SS planned and supervised the work and finalized the manuscript. Both the authors approved the final version of the manuscript.

\section{REFERENCES}

1. Modi A, Mishra V, Bhatt A, Jain A, Mansoori MH, Gurnany E, et al. Delonix regia: Historic perspectives and modern phytochemical and pharmacological researches. Chin J Nat Med 2016;4:31-9.

2. Sharma S, Arora S. Phytochemicals and pharmaceutical potential of Delonix regia (Bojer Ex Hook) Raf a review. Int J Pharm Pharm Sci 2015;7:17-9.

3. Khare CP. Indian Medicinal Plants, An Illustrated Dictionary. $1^{\text {st }}$ ed. New Delhi: Springer; 2007. p. 812.

4. Parke DV, Lewis DF. Safety aspects of food preservatives. Food Addit Contam 1992;9:561-7.

5. Davidson PM, Taylor MT. Chemical preservatives and natural antimicrobial compounds. In: Doyle M, Beuchat L, editors. Food Microbiology: Fundamentals and Frontiers. Washington, DC: ASM; 2007. p. 713-5.

6. Velioglu YS, Mazza G, Gao L, Oomah BD. Antioxidant activity and total phenolics in selected fruits, vegetables and grain products. J Agric Food Chem 1998;46:4113-17.

7. Sultanova N, Makhmoor T, Abilov ZA, Parween Z, Omurkamzinava VB, ur-Rahman A, Choudhary IM. Antioxidant and antimicrobial activities of Tamarix ramosissima. J Ethnopharmacol 2001;78:201-5.

8. Re R, Pellegrini N, Proteggente A, Pannala A, Yang M, Rice-Evans C. Antioxidant activity applying an improved ABTS radical. Free Radic Biol Med 1998;26:1231-37.

9. Klancnik A, Piskernik S, Jeršek B, Možina SS. Evaluation of diffusion and dilution methods to determine the antibacterial activity of plant extracts. J Microbiol Methods 2010;81:121-6.

10. Zhang W, Wang Y, Tian RM, Bougouffa S, Yang B, Cao HL, et al. Species sorting during biofilm assembly by artificial substrates deployed in a cold seep system. Sci Rep 2015;4:6647-54

11. Rackova L, Oblozinsky M, Kostalova D, Kettmann V, Bezakova L. Free radical scavenging activity and lipoxygenase inhibition of Mahonia aquifolium extract and isoquinoline alkaloids. J Inflammation 2007:4:15-1

12. Sekhar S, Sampathkumara KK, Niranjana SR, Prakash HS. Bioactive potential of medicinal plants from Western Ghats region, India. J Herbs Spices Med Plants 2014;20:221-4.

13. Choi JY, Desta KT, Lee SJ, Kim YH, Shin SC, Kim GS, et al. LC$\mathrm{MS} / \mathrm{MS}$ profiling of polyphenol-enriched leaf, stem and root extracts of Korean Humulus japonicus Siebold and Zucc and determination of their antioxidant effects. Biomed Chromatogr 2018;32:1-8.

14. Lee JC, Kim HR, Kim J, Jang YS. Antioxidant activity of ethanol extract of the stem of Opuntia ficus-indica var. Saboten. J Agric Food Chem 2002;50:1619-24.

15. Peterson J, Dwyer J. Flavonoids: Dietary occurrence and biochemical activity. Nutr Res 1998;18:1995-98.

16. Semaming Y, Pannengpetch P, Chattipakorn SC, Chattipakorn N. Pharmacological properties of protocatechuic acid and its potential roles as complementary medicine. Evid Based Complement Alternat Med 2015;2015:593902

17. Jafari N, Zargar SJ, Delnavazi MR, Yassa N. Cell cycle arrest and apoptosis induction of phloroacetophenone glycosides and caffeoylquinic acid derivatives in gastric adenocarcinoma (AGS) cells. Anticancer Agents Med Chem 2008;18:610-6.

18. Lin Y, Shi R, Wang X, Shen HM. Luteolin, a flavonoid with potentials for cancer prevention and therapy. Curr Cancer Drug Targets 2008;8:634-6.

19. Brito A, Ramirez JE, Areche C, Sepúlveda B, Simirgiotis MJ. HPLCUV-MS profiles of phenolic compounds and antioxidant activity of fruits from three citrus species consumed in Northern Chile. Molecules 2014;19:17400-21.

20. Spínola V, Pinto J, Castilho PC. Identification and quantification of phenolic compounds of selected fruits from Madeira Island by HPLCDAD-ESI-MSn and screening for their antioxidant activity. Food Chem 2015;173:14-30.

21. Lin LZ, Harnly JM. Identification of the phenolic components of chrysanthemum flower (Chrysanthemum morifolium Ramat). Food Chem 2010;120:319-6.

22. Chaira $\mathrm{T}$, Barman $\mathrm{T}$, Raj VS. In vitro ADME, preclinical pharmacokinetics and prediction of human pharmacokinetics of RBx14255, a novel ketolide with pharmacodynamics against multidrugresistant bacterial pathogens. Int J Pharm Pharm Sci 2020;23:206-9.

23. Ali S, Sheikh K, Amber R. Review on antibacterial activity of Himalayan medicinal plants traditionally used to treat pneumonia and tuberculosis. J Pharm Pharmacol 2019;71:1599-25.

24. Jose BS, Martin R. Simarouba glauca bark extract mediated synthesis and characterization of iron oxide and silver nano particles and their antibacterial, cytotoxic and photocatalytic activity. IJPPS 2020;12:9-2.

25. Kokila NR, Mahesh B, Mruthunjaya K. Exploration of bioactive components of Thunbergia coccinea, its pharmacognostic, antioxidant, GCMS and antihyperglycemic studies. IJPPS 2020;12:45-4.

26. Jain HK, Swami PN, Gujar KN. Formulation and evaluation of an antimicrobial mucoadhesive dental gel of Azadirachta indica and Glycyrrhiza glabra. IJAP 2019;11:176-84. 